\title{
The Review of Water Use Efficiency and Water Productivity Metrics and Their Role in Sustainable Water Resources Management
}

\author{
Dominico B. Kilemo \\ Department of Animal, Aquaculture and Range Sciences, College of Agriculture, Sokoine University of Agriculture, Morogoro, \\ Tanzania \\ Email: dbkilemo@yahoo.com
}

How to cite this paper: Kilemo, D.B. (2022) The Review of Water Use Efficiency and Water Productivity Metrics and Their Role in Sustainable Water Resources Management. Open Access Library Journal, 9: e7075. https://doi.org/10.4236/oalib.1107075

Received: October 7, 2021

Accepted: January 25, 2022

Published: January 28, 2022

Copyright $\odot 2022$ by author(s) and Open Access Library Inc.

This work is licensed under the Creative Commons Attribution International License (CC BY 4.0).

http://creativecommons.org/licenses/by/4.0/ (c) (i) Open Access

\begin{abstract}
Our planet faces a challenge of producing food to meet the demand of current population which is projected to increase by the year 2050 . This implies producing more food from the existing fresh water resources which are already stressed. This is because agriculture accounts for $70 \%$ global fresh water consumption; the rest is domestic and industrial use. Yet, water is unevenly distributed globally, causing some countries to be water-rich and others water-poor. Agricultural water management provides opportunities to optimize crop yield from less water. This necessitates a shift from conventional crop production approaches which aimed at maximizing yield per unit area of land to more water conscious methods that seek to maximize crop yield per unit water consumption which is determined by evapotranspiration. Water Use Efficiency (WUE) and Crop Water Productivity (CWP) are water accounting metrics aimed at monitoring the efficiency with which water is supplied to the field and the rate at which the plant converts water into food respectively. This paper reviews these metrics by examining their differences, assessing their contribution to sustainable water management, factors affecting each of them and strategies for increasing both metrics. Findings from literature suggest that WUE and CWP are different terms, but often misused especially WUE which is wrongly applied in the contexts meant for CWP. Factors affecting CWP which must be also considered in devising strategies for increasing it can be grouped into crop specific factors, climate factors and management factors. The paper recommends a number of interventions aiming at increasing WUE and CWP from local to global scale. These include provision of technical and financial support to developing counties to enable reduce water wastage, benefit from rainfall through rain harvesting technologies and low cost irrigation infrastructures that reduce evaporation, runoff and deep percolation
\end{abstract}


losses. Water-poor countries are recommended to grow high value crops and use the proceeds to import food from water-rich countries under virtual water trade agreements.

\section{Subject Areas}

Hydrology

\section{Keywords}

Water Resources Management, Water Use Efficiency (WUE), Crop Water Productivity (CWP)

\section{Introduction}

According to UNEP (2002) about 3\% of earth's water is fresh, the rest is saltwater which is unsuitable for human consumption. Of this, $2.5 \%$ occurs as permanent snow cover in the Antarctica and Arctic regions and in glaciers. Thus it is only $0.5 \%$ which is available for human consumption and other life forms that depend on freshwater (UNEP, 2002 [1]; UNESCO, 2003 [2]). At global scale, freshwater stress and food production are twin challenges facing the society (Alcamo et al., 2007) [3]. This is exacerbated by a rapidly growing world population which puts more pressure on water due to increased food production (Zwart et al., 2004) [4]. Because more people will need more food. While the population is increasing, land and water do not increase. Food production has to be undertaken on the existing land and water (Wallace, 2000) [5]. The challenge is how to increase food production without increasing water consumption. Agriculture is the largest global consumer of freshwater (both green and blue water) accounting for $70 \%$ of fresh water use (UNESCO, 2003) [2]. It competes with industrial and domestic sectors in water consumption. While in low-income and middle-income countries $82 \%$ of fresh water is used for agriculture, in high-income countries $59 \%$ is used in the industrial sector, agricultural use only accounts for $30 \%$ of water use (UNESCO, 2003) [2]. This suggests that water stress is likely to severely affect low-income and middle-income countries which are characterized by small scale agriculture coupled with poor farming and irrigation methods that lead to unnecessary water wastage. This is attributed among others to limited technical and financial capacity to apply modern farming and irrigation methods which conserve water and increase crop yield.

Agriculture is divided into rainfed and irrigated farming. Rainfed agriculture is the most common type of farming practiced worldwide covering $80 \%$ of cultivated land and accounting for $60 \%$ of global food production (UNCTAD, 2011) [6]. In areas where there is reliable and adequate rainfall like in UK and other parts of northern Europe, agricultural production is reliable and crop yield is high (UNESCO, 2003) [2]. But in areas where rainfall is low, erratic, and unreliable like the drier regions of Africa where many of the poor live, crop yields are 
low and uncertain (UNCTAD, 2011) [6]. In such regions water consumption is very high due to high evapotranspiration rates. The smallholder farmers have limited capacity to wisely and effectively use the rainwater, much of it is lost unproductively. Water wastage in both rainfed and irrigated agriculture is among of the reasons for water stress. It is important that much of the irrigated or rain water enters the plant transpiration system, because that is the only way water will be used by plants leading to crop yield. However, in real field conditions less water is used by crops as transpiration. According to Wallace (2000) [5], globally only $10 \%-30 \%$ of rainfall is used for crop transpiration. Sometimes such percentage can be as low as 5\% especially in semi arid areas (Rockstrom and Falkenmark, 2000) [7]. The remaining fraction is lost through surface runoff, drainage, and unproductive evaporation (IWMI, 2009) [8]. While in rainfed agriculture land management practices is responsible for evaporation and runoff losses of water, in irrigated agriculture water loss through evaporation is attributed to poor irrigation management (Wallace, 2000) [5]. In South Mediterranean region where water supply is limited, Lacirignola et al. (2014) [9] report that the agricultural sector consumes more than $80 \%$ of renewable water resources. They further argue that an increase of $10 \%$ in agricultural water use efficiency would provide $40 \%$ additional water for industrial and domestic use. Considering the complexities of water use pattern in food production systems across the globe, addressing water and food challenges must be done in an integrated approach and not in isolation (Rockström and Karlberg, 2010) [10]. With the increasing trend of population growth that will create more food demand, if no appropriate measures are taken there is a risk of depleting the earth's vast fresh water resources (Brauman et al. 2013) [11]. Water Use Efficiency (WUE) and Water Productivity (WP) are indices used for ensuring water saving and thus contributing to sustainable agricultural water management. A higher agricultural WP leads to either the same production from less water resources or a higher production from the same water resources (Zwart and Bastiaanssen, 2004) [4]. Furthermore, WP concept can be applied in other contexts apart from agricultural production, e.g. in livestock production, fisheries, tree plantations and irrigation system (IWMI, 2007) [12]. WUE and WP are well known terms in agricultural water consumption. WUE expresses the ratio or percentage at which water input into an agricultural system reaches and is absorbed by the target crops while WP equates the water used by the crop with benefit produced (conversion of water into food). However, there has been a lack of consensus and consistency across various disciplines on the usage of such terms (Sadras et al. 2011 [13], Ragab, 2016 [14]). In particular, there has been a misuse of the term WUE, wrongly expressing it as a ratio of biomass production to water consumed. In reality a ratio of biomass produced to water consumed defines water productivity. The "catchy" nature of the term "water use efficiency" tempts many scientists to use it even in contexts where it doesn't apply. Therefore WUE and WP are different terms and cannot be used interchangeably. Although the terms are closely related, a high WUE does not necessarily lead to high WP be- 
cause WP is plant specific and is controlled by other factors (Zwart and Bastiaanssen, 2004 [4]; Sadras et al. 2011 [13]). Section 2 of this manuscript provides an in-depth review of the two terms. In order to enhance agricultural water management, there is a need to have a general consensus in definition of the terms so that all actors in the agriculture sector can arguably have a common understanding. This will facilitate the formulation of integrated water resources management plans from plot to basin scale. Water as a natural resource cuts across different sectors and academic disciplines. Thus its management requires converted efforts from all stakeholders. But if the stakeholders don't have a common metric for water accounting, the management strategies implemented in one disciple might be counterproductive in other discipline. Therefore, there is a need to have a standard metric that is applicable in all disciplines and sectors.

Sustainable Water Resources Management (SWRM) embraces the fundamental definition of sustainable development as stated in the Brundtland Report (UNWCED, 1987) [15]. It is defined as the development capable of meeting the needs of present generation without compromising the ability of future generations to meet their own needs. Needs refer to ecosystem goods and services, benefits which people get from the ecosystems as they pursue development. Water resources are critical and integral component of human life, thus they are directly related to sustainable development. SWRM can therefore be defined as the utilization of water resources to meet human needs in a manner that does not impair future availability. Mays (2006) [16] define SWRM as the ability to meet current water demand for all water users without affecting future supply. Furthermore, the Agenda 21 (UNCESD, 1992) recognizes that water is needed in all aspects of life. One of its objectives is to "make certain that adequate supplies of water of good quality are maintained for the entire population of the planet, while preserving the hydrological, biological and chemical functions of ecosystems, adapting human activities within the capacity limits of nature and to combat vectors of water-related diseases". Sustainable development encompasses three components of sustainability or sometimes referred to a sustainability triangle. These include economic, environmental and social components or economical, ecological and human components (Russo, Alfredo et al. 2014 [17]; Gogan et al. 2015 [18]). SWRM also integrates such three dimensions of sustainability ensuring that it contributes to economic, environmental and social development. This paper reviews WUE and WP in the context of sustainable water resources management. The paper seeks to achieve the following objectives: 1) review definitions of WUE and WP and unveil their differences 2) analyze factors influencing crop water productivity (CWP) 3) examine the contribution of WUE and WP in sustainable water resources management 4) examine strategies for increasing CWP in both irrigated and rain fed agriculture 5) analyze the constrains for achieving optimal CWP and sustainable water resource management.

\section{Definitions and Measurement of WP and WUE}

Molden et al. (2010) [19] define WP as the ratio of the net benefits from crop, 
forestry, fishery, livestock and mixed agricultural systems to the amount of water used to produce those benefits. Thus the term means different things to different people (Passioura, 2005) [20]. But the key principle is that the benefit obtained is equated with the amount of water used to produce that particular benefit. The numerator must be the quantity or value of the benefit while the denominator is water used. Therefore, CWP can be defined as the ratio of yield (marketable portion) to water consumed by the plant, expressed in $\mathrm{Kg} / \mathrm{m}^{3}$ (Zwart and Bastiaanssen, 2004) [4]. While WP is a straight forward, easy to understand term, WUE seems to be ambiguous as it is sometimes confused with WP. The use of "water use efficiency" terminology has been at the center of debate for many decades due to differing perspectives in defining it across various disciplines, particularly engineering, irrigation, crop agronomy and crop physiology (Sadras et al. 2011) [13]. The confusion was greatly caused by crop physiologists and agronomists who associated biomass production with water consumption in defining WUE (e.g. Viets, 1962 [21], 1966 [22]; Condon et al. 2002 [23]; Medrano et al. 2010 [24]). What they were referring to as WUE was in actual sense WP and sometimes they used both terms interchangeably. This raised a lot of concerns among water resources management and irrigation community. Many proponents of correct use of the term WUE published journal articles calling for the correct use of the terminology and provided a clear distinction between water productivity and water use efficiency (e.g. Meldon, 2010 [19], Ragab, 2016 [14]). According to these authors WUE metric simply measures the efficiency of the system in making water available to the plants, measured as the ratio of water availed to the plants (root zone) to water supplied from the source. It does not consider the benefit (yield) produced from the applied water (Seckler et al. 2003) [25]. The system supplying water to the plants may be an irrigation system or rainfall. The key question is how much of the irrigation water is actually absorbed and transpired by the plants? Or how much of the rainfall water is availed to the plants. As pointed out earlier, for irrigation water the limiting factor is the irrigation technology and management, whereas for rainfall water; land management and climate conditions may influence how much water is stored in the root zone and thus available to the plants. A poorly management land may lead to high evaporation from soil surface, low infiltration rate and high runoff causing much of the rainfall water to be lost (unusable by plants) though will still be used by other users downstream. Therefore, considering WUE of that particular land, it can be found that the ratio of water used by the plants to the rainfall water supplied is low.

In a move to end the confusions of using WUE and WP, the Food and Agriculture Organization (FAO), intervened whereby the use of the term "efficiency" is reserved for engineering application and the term "water productivity" for agricultural ratios such as yield per unit evapotranspiration or yield per water supplied (Sadras et al. 2011) [13]. Other international organizations such as International Water Management Institute (IWMI) (Cai et al. 2010) [26] and In- 
ternational Commission on Irrigation and Drainage (ICID) (Perry, 2011) [27] also agree with FAO distinction of the terms. This restriction has been adopted by some high impact peer reviewed journals such as Agriculture Water Management, Journal for Irrigation and Drainage whereby they do not accept papers substituting WP for WUE (Ragab, 2016) [14]. The classical meaning of the term "efficiency" suggests that it is a dimensionless metric usually expressed as a ratio or percentage. Its use originated in the field of engineering, relating quantities of the same unit (Seckler et al. 2003) [25] though it was criticized for considering water not used by plants as "lost water" (Jensen, 1967) [28], before being revised in what is called neoclassical irrigation efficiency (Seckler et al. 2003) [25]. Considering water balance components, the irrigation water balance can be expressed as defined in Jensen (2007) [29] as follows:

$$
W_{g}=E+T+\Delta S+R+D
$$

where $W_{g}$ is the gross volume of water delivered to a field or farm including effective precipitation, $P_{e}$ (precipitation that reduces the quantity of irrigation water needed). $E$ is evaporation from soil and plant surfaces, $T$ is transpiration while $\Delta S$ is change in water storage at plant root zone. $R$ is surface runoff and $D$ is drainage below root zone. The components $E$ and $T$ when combined form a term Evapotranspiration which represents water consumed by plants. When evaluating the performance of an irrigation system, the term irrigation efficiency is used and is hereby referred to as classical efficiency (CE) (Seckler et al. 2003) [25]. It then follows that:

$$
C E=\frac{E T}{W_{g}-P_{g}}
$$

where $E T$ is the portion of irrigation water that was consumed by plants, $W_{g}$ is the gross water supply and $P_{e}$ is effective precipitation. This classical definition of irrigation efficiency considers water not consumed by plants (i.e. surface runoff water and percolated water) as lost by the system, but in reality the water is not lost by the hydrological system. It is reused or used by other users downstream of the basin. This weakness was first addressed by Jensen (1967) [28] who revised the classical definition by factoring in the surface runoff and deep percolation components which was regarded as "inefficiency" portion of the irrigation system. Thus according to him the revised classical efficiency, referred to as net efficiency $(N E)$ is given by:

$$
N E=C E+C E(1-C E)
$$

For example if $20 \mathrm{~mm}$ of water is applied to the field (assuming no precipitation), $12 \mathrm{~mm}$ reaches the root zone and is absorbed by plants (ET portion); 5 $\mathrm{mm}$ flows out of root zone as deep percolation and $3 \mathrm{~mm}$ flows out as surface runoff, $C E$ is calculated as:

$C E=12 / 20=0.6$ or $60 \%$. Thus the efficiency of the system is $60 \%$. This implies that $1-0.6$ is a portion of water lost through percolation and surface runoff. Using the NE, the efficiency can be recalculated using Equation (3) as: 


$$
N E=0.6+0.6(1-0.6)=0.84 \text { or } 84 \% \text {. }
$$

Therefore, it can be found that when the neoclassical definition of irrigation efficiency is used, there is an improvement of efficiency value. According to Heydari (2014) [30], the term irrigation efficiency was first introduced by Israelsen (1950) [31] who defined it as the ratio of the irrigation water consumed by the crops of an irrigated field to the water diverted from a river or other natural water source into the irrigation system canal or canals. Since then the term was used for many years until when Viets (1966) [22] introduced the term WUE and defined it as the ratio of crop production to evapotranspiration. This agronomic and crop production-oriented view on the efficient use of water differs from the engineering definition of irrigation efficiency (Heydari, 2014) [30]. Such view would have made sense if it referred to WP since it associates water consumed and the benefit obtained. Molden (1997) [32] coined the broader term water productivity for analysis of water use at different scales. This was supported by Kijne et al. (2003) [25] who defined the agricultural perspective on water productivity as measure of the ability of agricultural systems to convert water into food.

The current focus of water productivity has evolved to include the benefits and costs of water used for agriculture in terrestrial and aquatic ecosystems (Molden et al. 2010) [19]. According to Sharma et al. (2015) [33], WP is estimated from the amount of water directly consumed by the agricultural system (evaporation and transpiration) and not the amount of irrigation water applied or rainfall received. From field to farm to watershed, it can be found that the water that is taken into the system but not consumed by the plants is available downstream. Hence it is normally excluded from the calculation (Sharma et al. 2015) [33]. This paper adopts the agricultural WP and WUE definitions endorsed by FAO, IWMI and ICID because they are authoritative and are based on the consensus of internationally recognized experts in the field agriculture, water management and irrigation science. Although this paper takes an opposing view on the use of the term WUE by agronomy, crop physiology and plant ecology authors who erroneously refer WP as WUE, the contents of the literature is still valid and true if WUE is replaced by WP concept. Therefore, their literatures are still cited but the context is twisted to imply WP.

WP can be defined and measured at different spatial and temporal scales. According to Condon et al. (2002) [23] WP can be defined at plot, plant and leaf levels. At plot level, WP is expressed as the ratio of total yield to evapotranspiration, whereas at both plant and leaf level is expressed as the ratio of biomass produced to transpiration. At leaf level where biomass production and gaseous exchange takes place through photosynthesis and respiration respectively, the WP is calculated as a ratio of instantaneously assimilated carbon dioxide to leaf transpiration .Temporal scale involves the growth period of the plant, from minutes to months. The short term scale (minutes) is best suited for leaf level measurement while the long term scale enables plant level and plot level mea- 
surements. In computing WP at crop level (CWP) and basin level, quantification of water used includes water transpired by plants and water which was not transpired, normally the water lost through direct soil evaporation, deep percolation and surface runoff (Medrano et al. 2010) [24].

Measurement of WP at leaf level is done using gas exchange systems near steady-state conditions in the field, obtaining an instantaneous and non destructive measurement that reflects the leaf capacity for transpiration productivity (Medrano et al. 2015) [34]. In order to measure whole plant WP, plant transpiration must be determined besides biomass accumulated. This is made possible through gravimetric methods in potted plants. However, canopies of potted plants does not match well with real canopies in the crop, and the root development is hampered which could modify plant development. Alternatively, lysimeters or sap flow meters (for woody plants) are other techniques that can be used for measurements of plant water consumption in the field (Cirelli, Lieffers, and Tyree 2012) [35]. Eddy covariance techniques are recommended to be well suited to capture data on carbon and water fluxes at local, regional and global scales (Spano et al. 2004 [36]; Tang et al. 2014 [37]). Therefore, it is a reliable approach to provide estimates for plant WP. This can be applied also at watershed scale. Generally, at watershed scale, regional scale and global scale an ecosystem approach is used with a help of simulation models and eddy covariance towers which record hourly fluxes of water, carbon dioxide and energy.

Vanloocke et al., (2012) [38] applied an agro-ecosystem model to assesses WP of 3 different bioenergy feedstocks, 2 grass species and maize at regional scale. Key to their work was the trade-offs between evapotranspiration and carbon uptake. Their assessment was done at ecosystem and biome scales. Assessment of ecosystem WP applies the ecological principle whereby the ecosystem net primary production is obtained by subtracting respiration from the gross primary production. Both below ground and above ground carbon stocks are included in the calculation. Thus ecosystem WP is a ratio of net ecosystem production to total ecosystem evapotranspiration. A biome contains more than one ecosystem. At biome level, dynamics of carbon and water fluxes are easier to monitor than at ecosystem level; because changes at ecosystem level may be undetectable as they are infrequent. But considering many ecosystems at biome level the changes may be easy to detect. The net biome production is calculated by subtracting disturbance losses from the net ecosystem production. To obtain biome WP, the total net biome production is divided by total biome evapotranspiration. Vanloocke et al., (2012) [38] also incorporated a harvesting scheme in their modeling strategy to quantify the amount of carbon removed from the ecosystem which was mainly the above ground carbon. Therefore at the end they had three metrics which were used to assess water productivity, namely harvest WP, ecosystem WP and biome WP. The metrics varied across the studied feedstocks at different spatial scales. Their findings suggest that large scale production of biofuel feedstocks should take into account the water productivity of particular species so that only water saving species are grown. A global scale assessment of WP 
of terrestrial ecosystems by Tang et al. (2014) [37] provides more insights into approaches and methods for measurement of WP of various plant functional types at ecosystem and regional scales. They made use of data from several sites which are jointly shared through FLUXNET, a global network of eddy covariance towers which capture water vapor, carbon dioxide and energy fluxes for various plant functional types at different temporal and spatial scales (Cook et al. 2007) [39]. These data were used to evaluate the output of MODIS, a remote sensing platform used for estimating gross primary production and evapotranspiration at global scale (Tang et al. 2014) [37].

\section{Factors Influencing Crop Water Productivity}

Crop water productivity is controlled by a number of factors which can be grouped into three, plant specific factors, climate factors and management factors. These factors influence the biomass accumulation per unit transpiration and crop yield per seasonal evapotranspiration. CWP as a ratio of yield to water consumed can be evaluated by assessing what happens at the numerator (yield) and the size of denominator (water consumed). Low CWP will be achieved if the numerator is smaller than the denominator. Increasing CWP means reducing the denominator while the numerator increases. However, it is important to note that some water must be used by the plants to achieve yield. CWP index seeks to optimize yield from less water as much as possible. Management to improve CWP depends on reducing losses to soil evaporation, maximizing transpiration, and improving transpiration productivity by growing crops under conditions of low atmospheric evaporative demand (Connor et al., 2011) [40].

\subsection{Plant Factors}

C3 and C4 plants differ in the metabolic pathway of photosynthesis. Because of this, the trade-off between photosynthetic leaf carbon assimilation and water loss varies among these two plant groups and normally is higher in C4 plants. For example, maize and sorghum have higher yield per unit seasonal transpiration compared with their C3 counterparts, wheat and barley (Sadras et al. 2011) [13]. A work by Zwart and Bastiaanssen (2004) [4] which assessed CWP of irrigated wheat, rice, cotton and maize further confirms this fact. Genetically, some plants have evolved with metabolic traits enabling them to achieve high yield under limited water conditions. This accounts for CWP differences among crops some of which are of the same species. For example, a study of five different varieties of chickpeas by Silva et al. (2014) [41] in contrasting wet and dry conditions under supplementary irrigation found that Elixir variety was the one that presented the best results, with the highest grain yields and water productivity values, in both dry and wet year conditions, making it the best option for farmers. Moreover, drought resistance by some crops is also attributed to genotypic make up.

\subsection{Climate Factors}

Rainfall patterns, evaporative demand of the atmosphere and vapor pressure 
deficit (VPD) (the difference between the saturation vapor pressure and the actual vapor pressure) are main climate variables controlling yield per unit of evapotranspiration. VPD has significant influence on CWP, thus understanding its influence helps to make appropriate management decisions such as crop choice, sowing date and fertilizer rate (Sadras and McDonald, 2012) [42]. The evaporative demand of the atmosphere is substantially driven by the vapor pressure deficit and net radiation, a key energy source for photosynthesis and evapotranspiration. Net radiation $(\mathrm{Rn})$ is divided into sensible heat $(\mathrm{H})$ and latent heat (LE). Rn fluxes within plant canopy lead to different microclimates which influence evapotranspiration (Connor et al. 2011) [40]. But this will depend on whether the prevailing condition is wet or dry. In wet conditions, energy is the limiting factor $(\mathrm{LE}>\mathrm{H})$. Hence evaporative demand is low. Crop transpiration will be regulated by the vapor pressure deficit (which is also low in wet conditions) and crops are expected to have high yield. On the other hand, in dry conditions, $\mathrm{H}$ is greater than LE which causes high evaporative demand of the atmosphere. The little available water will be lost through evaporation and VPD will be high causing crops to experience a stressful transpiration, thus leading low crop yield. Since saturation vapor pressure increases exponentially with temperature (Figure 1), VPD increases exponentially when temperature increases and absolute humidity remain constant (Will et al., 2013) [43].

Higher VPD causes physiological stress on plants during drought through either increasing plant water loss or reducing carbon uptake (McDowell et al.,

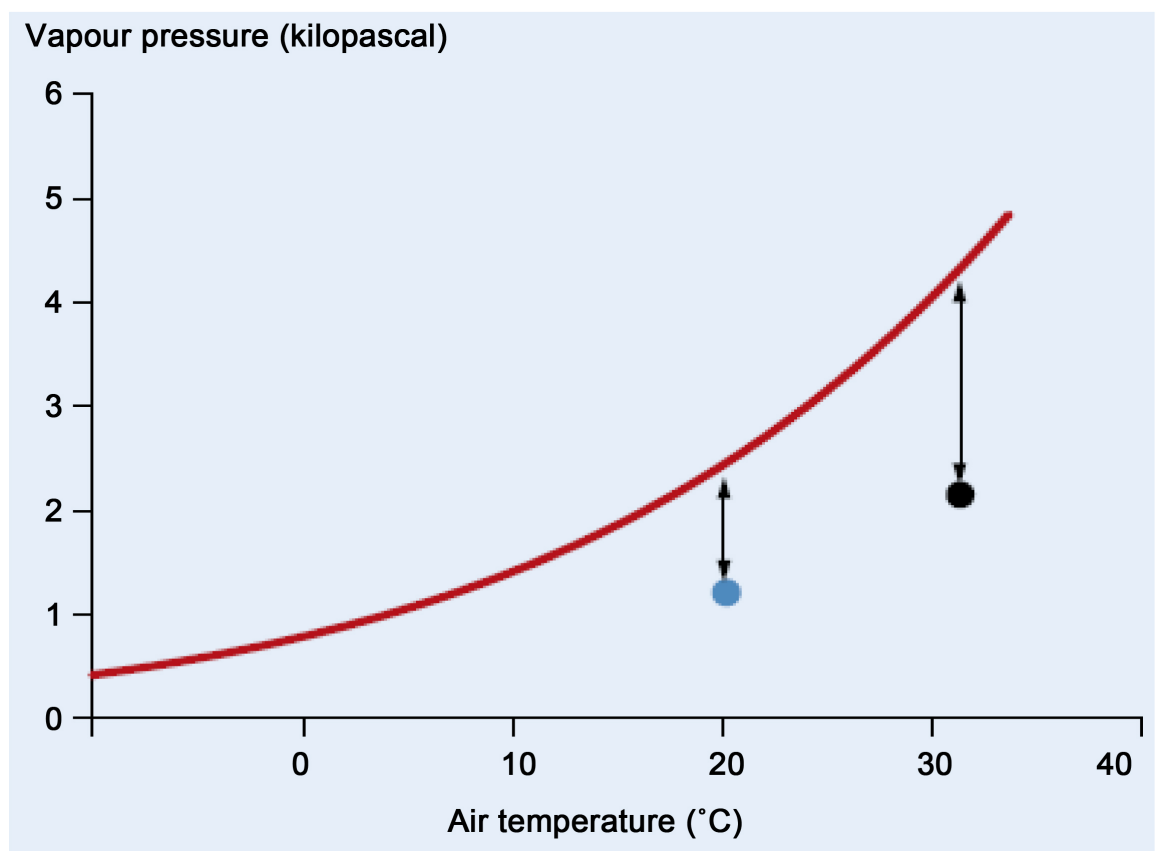

Figure 1. The vapor pressure saturation curve: The blue point shows the actual vapor pressure at $20^{\circ} \mathrm{C}$ for a relative humidity of 50 per cent. The black point shows the actual vapor pressure at $30^{\circ} \mathrm{C}$ for a relative humidity of 50 per cent. The arrows show the vapor pressure deficit, which is the gap between actual and saturated (Sadras and McDonald, 2012) [42]. 
2008) [44]. Plants normally have physiological mechanisms to cope with water stress conditions by limiting transpiration through stomata in leaf cells. Transpiration resistance by stomata at high VPD seems to emanate from limiting hydraulic conductance in the plant, which restricts the flow of water from roots to transpiration sites in the leaf surface (Sinclair et al. 2008) [45].

A study by Zwart and Bastiaanssen (2004) demonstrated that VPD is inversely proportional to CWP. Moving away from the equator, temperature decreases and so is the VPD. Thus CWP increases with increasing latitudes (Zwart and Bastiaanssen 2004) [4]. The authors tested this hypothesis and found that that the highest CWP values occur between 30 and 40 degrees latitude where a factor 2 - 3 difference in CWP of wheat, rice and maize is detected when compared to areas between 10 and 20 degrees (Figure 2). This also confirms the proposition that location, season and sowing dates conducive to low evaporative demand of the atmosphere can potentially enhance yield per unit evapotranspiration (Sadras et al. 2011) [13].

Principally, rainfall is the main source water for terrestrial ecosystems, but it is seasonally available at different temporal and spatial scales due to climatic processes which are complex in nature, thus leading to the dynamics in water availability in agricultural systems. Water availability is the fundamental factor for sustaining crop productivity in rainfed agriculture. Therefore, an effective rainfall in optimal quantity is required to facilitate crop yield. As shown in Figure 3, the relationship between yield and water supply conforms to the law of

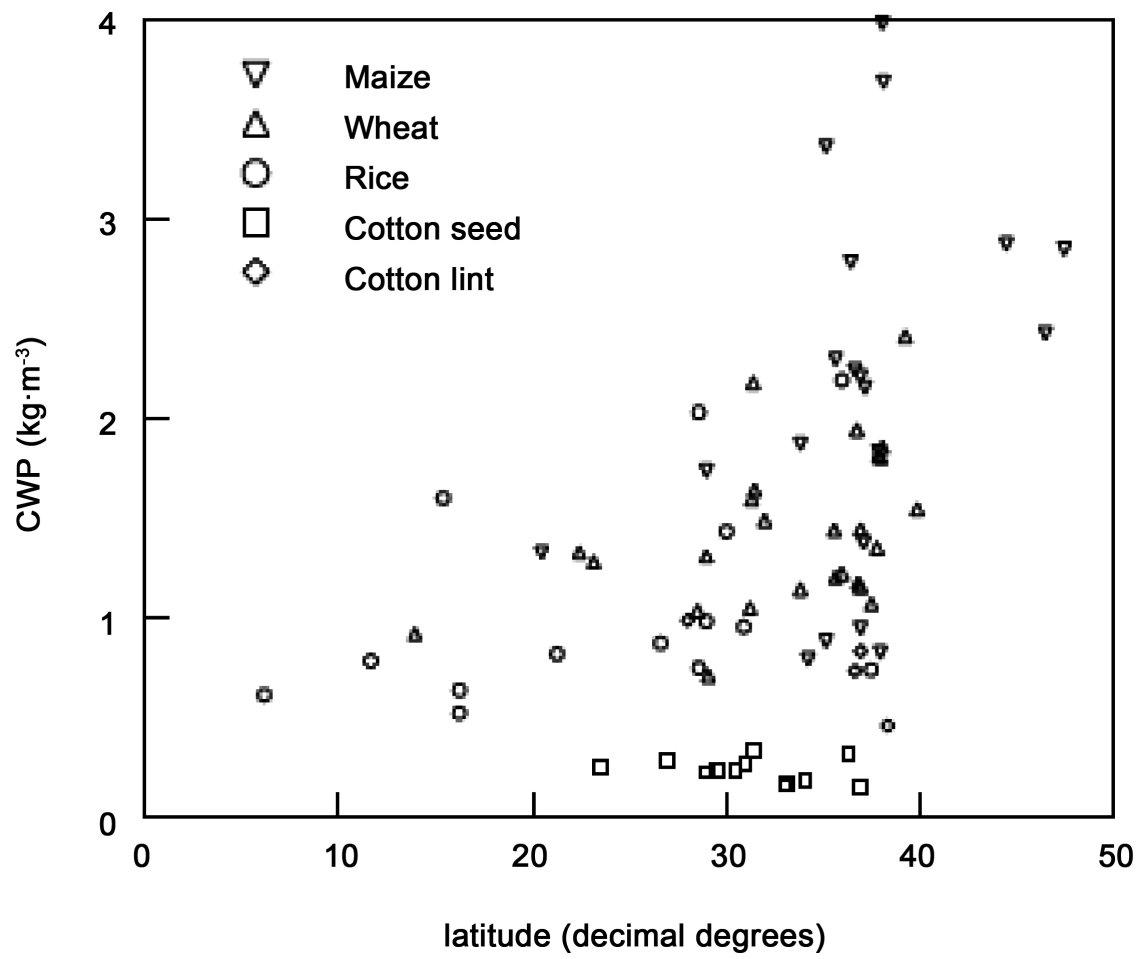

Figure 2. Relation between latitude and maximum crop water productivity (CWP) value per unit water depletion per location and per crop (Zwart and Bastiaanssen 2004) [4]. 


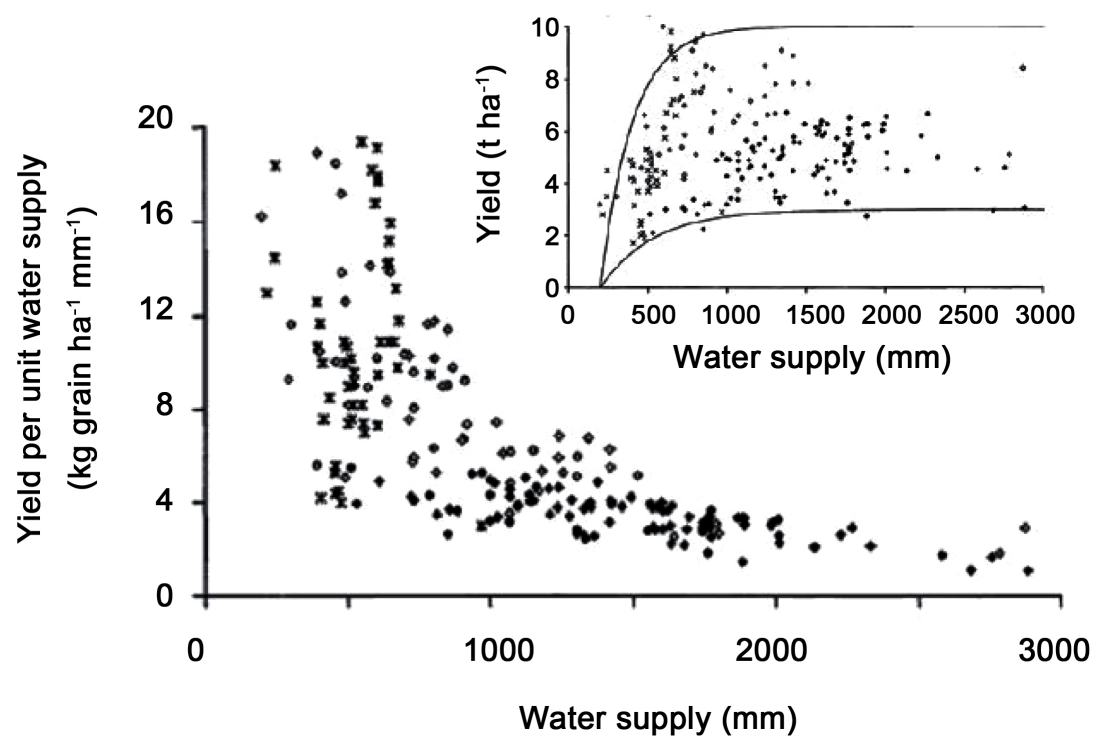

Figure 3. Inverse relationship between yield per unit water supply and water supply in rice. Water supply is seasonal irrigation and effective rainfall. Insert shows the relationship between yield and water supply (Sadras et al. 2011) [13].

diminishing returns, thus the decline in CWP with increasing water supply (Sadras et al. 2011) [13]. Moreover, excess water in cropping systems has detrimental effects on the yield quantity and quality due to waterlogging, conditions favoring diseases and leaching of nutrients and agrochemicals. Unlike in irrigated agriculture where the amount of water supplied to the field can be controlled, in rainfed agriculture the quantity of water supplied to the farm is determined by prevailing weather conditions. Thus the farmer has no control over rainfall pattern, but he/she can undertake adaptive management by establishing site conditions that removes excess water from the farm or maximize the effective rainfall amount.

\subsection{Management Factors}

Yield per unit evapotranspiration is also depended upon crop tending operations, water and land management. Management of non-beneficial transpiration, diseases control, irrigation management and soil management are discussed here. Non-beneficial transpiration is the transpiration that does not contribute to the yield of the target crop. This results from other plants mainly weeds that grow alongside the crop. If the weeds are not controlled, crop transpiration rate will be reduced which will translate into reduced yield. Because the weeds will be competing with the crop in water consumption. Thus computing yield over seasonal evapotranspiration will reveal a relatively large denominator (water consumption) and a small numerator (yield) hence a small CWP value. Plant diseases, especially those affecting the leaves, the food production machinery of the plants can adversely affect crop yield per unit evapotranspiration despite availability of suitable water and soil conditions for plant growth. The diseases must 
be controlled using appropriate means so as to enable crops achieve desirable water productivity. Grimmer et al. (2012) [46] reviewed the effects of foliar pathogens on plant water relations and the consequences for WP. Their findings suggest that the pathogens have deleterious effects on CWP such as impairment of stomatal opening in the light and impairment of stomatal closing in the dark. These have implications for the ability of the affected plant to assimilate $\mathrm{CO}_{2}$ for photosynthesis and the ability to conserve water respectively.

Poor irrigation technologies and management have been reported to cause low WUE and hence low CWP in water limited areas, especially in developing countries (Wallace, 2000 [5]; Lacirignola et al. 2014) [9]. Irrigation technologies that reduce evaporation, runoff and deep percolation losses are considered to be more efficient in supplying water to the crops and contribute to yield per unit of seasonal evapotranspiration. A study in Nepal by Jha et al. (2016) [47] compared the effect of furrow and drip irrigation system on WP of fodder crops. Their results indicate that drip irrigation had a higher CWP compared to furrow irrigation. This is attributed to its potential to reduce evaporation losses due to limited wetting of the soil. Its main disadvantage is the high installation costs which cannot be afforded by smallholder farmers. Low efficiency and low CWP of furrow irrigation is attributed to waterlogging due to excessive water application, excessive runoff losses and deep percolation losses that may also cause leaching of nutrients. Another important irrigation management aspect is irrigation scheduling. This is a practice whereby the farmer decides when to irrigate and how much water to be supplied. The goal of irrigation scheduling is to supply the plants with sufficient water while minimizing loss to evaporation, deep percolation or runoff. The scheduling varies with the plant development stages, i.e. vegetative stage, flowering stage and yield formation stage. The amount of water applied to each stage has implication on biomass accumulation (Igbadun et al., 2008 [48]; Zwart and Bastiaanssen 2004 [4]). Irrigation scheduling is commonly applied in deficit irrigation, an irrigation management method aimed at achieving maximum yield from low water input. Under this method, irrigation is purposefully carried out not to fully meet water requirements of the crop, and plants are allowed to extract soil moisture beyond readily available water in the plant root zone (Igbadun et al., 2008) [48]. A review of various experiments from various countries by Zwart and Bastiaanssen (2004) [4] found that without irrigation, CWP in rainfed production systems was low, but it rapidly increased when some irrigation water was applied. They further found that the optimum CWP values for wheat and maize were reached at approximately $150 \mathrm{~mm}$ and $280 \mathrm{~mm}$ of irrigation water applied (Figure 4(a) \& Figure 4(b)).

Soil management has implications on availability of nutrients to plants and the behavior of soil-water-plant relations. It is therefore important that soil is well managed so that CWP is enhanced. Nitrogen $(\mathrm{N})$ and Phosphorous $(\mathrm{P})$ and key nutrients observed to influence high yield. Thus if the soil has a low supply these nutrients, some fertilizers should be applied. However, care must be taken 


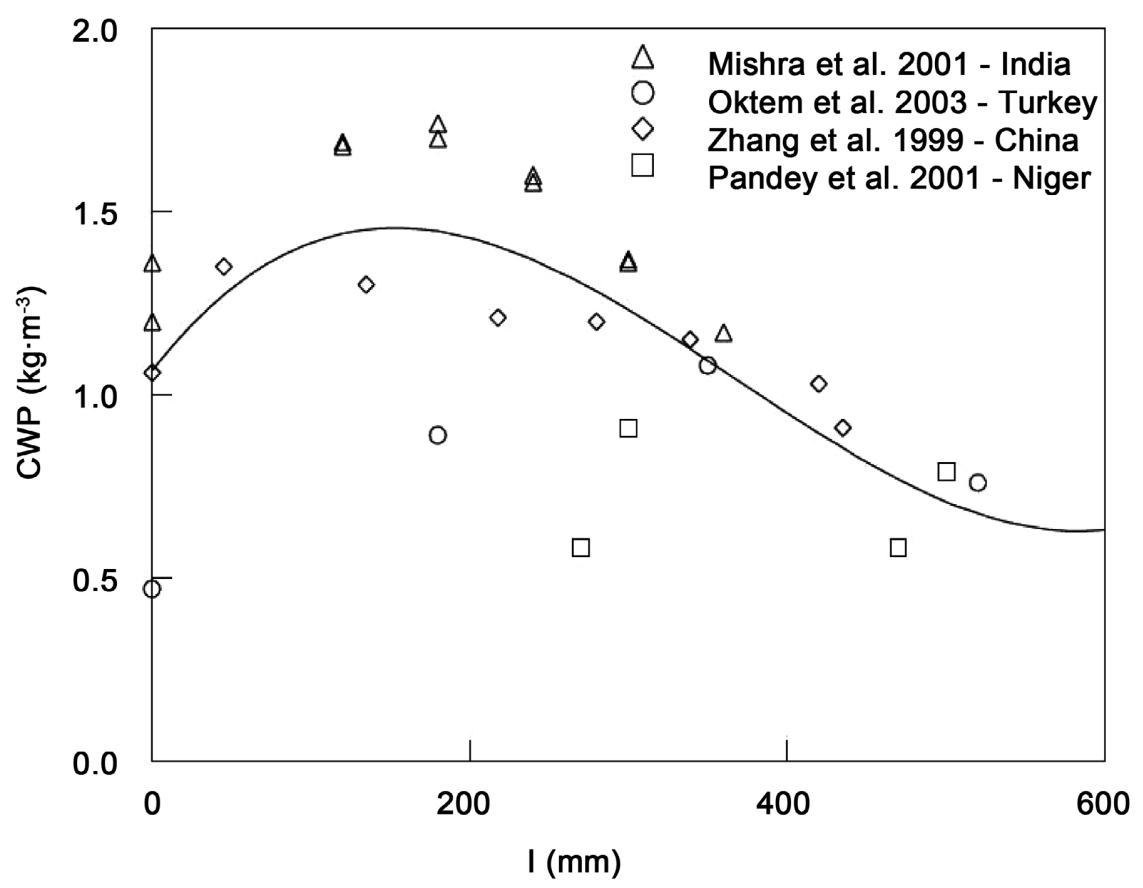

(a)

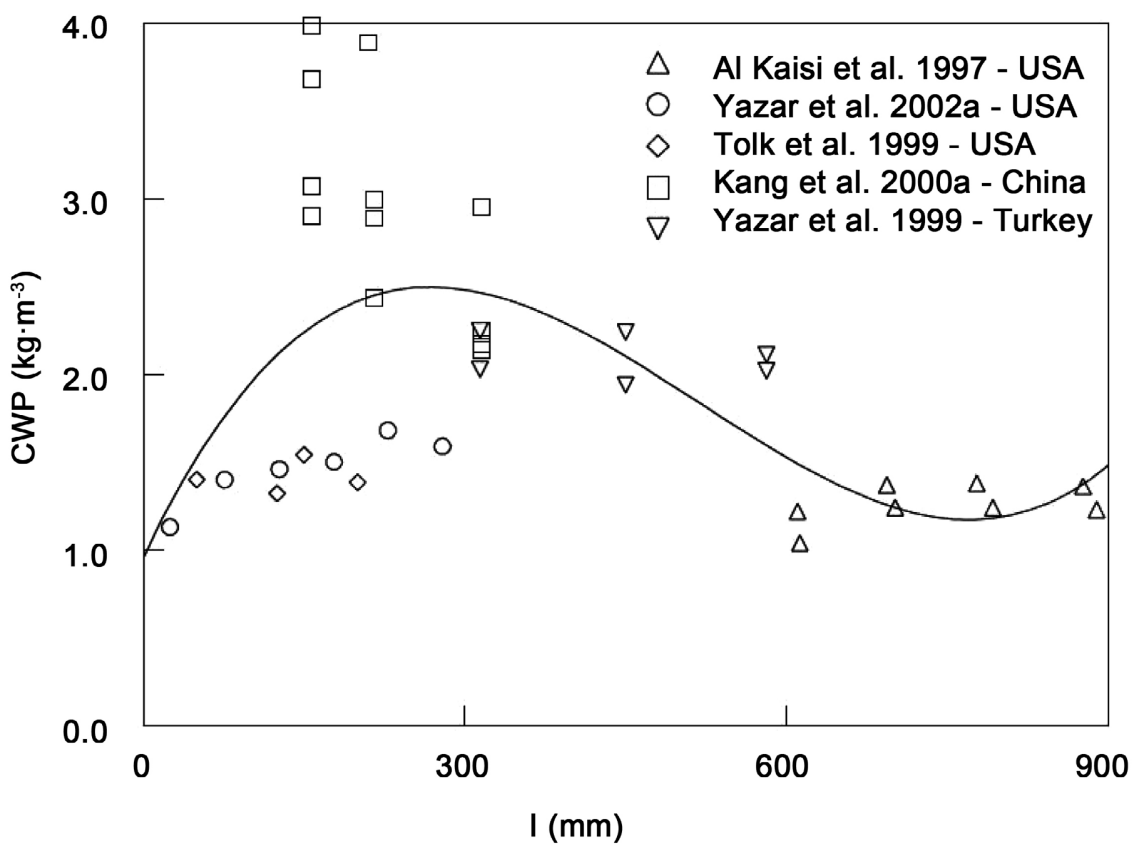

(b)

Figure 4. Relation between amount of irrigation water applied (I) and measured CWP per unit water depletion for (a) wheat and (b) maize (Zwart and Bastiaanssen 2004) [4].

so that optimal amounts are used. Studies on the effect of nutrient and water management on crop water productivity suggest that the effect of $\mathrm{N}$ and $\mathrm{P}$ or combined vary with the amount applied under given soil water conditions, excessive application of nutrient amount may decrease CWP (Li et al. 2001 [49]; Kröbel et al. 2012 [50]; Rudnick and Irmak, 2013 [51]). Implementation of soil 
and water conservation practices will influence both WUE and CWP. The practices include crop rotation, cover crops, mulching, terracing, contour bunds and tillage management. They are known to reduce soil erosion, runoff and soil evaporation losses. Soil infiltration rate will also be enhanced and thus enabling plants to have sufficient water. Reduction in soil erosion will enable the soil to retain plant nutrients. Proper implementation of these practices will lead to high yield per unit evapotranspiration (Hatfield et al., 2001) [52].

\section{Contribution of WUE and CWP in Sustainable Water Resources Management}

Sustainable water resources management is relevant in both water-rich and water-poor countries. These are countries with unlimited water supply and limited water supply respectively. This is attributed to the fact that water is unevenly distributed globally making some countries to have abundant supply of water and while others have very little supply. Despite such differences, water resources ought to be sustainably managed by all users to ensure future availability. According to UNESCO (2003) [2] developing countries are more likely to be affected by water stress due to higher dependence for agricultural production. Yet, the agricultural water management is very poor, water is not efficiently used leading to much of water being wasted unproductively. Irrigation systems are characterized by low efficiencies. This could be attributed to the fact that agriculture in developing countries is heavily dependent on smallholder farmers who lack skills and resources to implement sound agricultural water management practices for improved CWP (Wallace, 2000) [5].

Sustainable water resources management in agroecosystems aims to match available water and water demand in quantity and quality, in space and time under acceptable environmental conditions. The overarching goal is to ensure that agricultural water consumption does not hydrologically impair water availability for other users, improves livelihoods and contributes to social harmony. The application of WUE and CWP indices are envisaged to enable farm managers, watershed managers and policy makers to achieve water consumption levels that do not reduce future water availability. In semi-arid and arid areas substantial amount of water can be saved by installation of high WUE irrigation systems and undertaking some management interventions that lead to high CWP (section 5). By knowing the CWP benchmarks of crops, trees and other plants before they are grown, the limited water resources can be wisely budgeted to ensure sustainability.

\section{Strategies for Increasing CWP in both Irrigated and Rainfed Farming Systems}

Increasing crop yield per unit evapotranspiration is becoming a global obligation of every individual due to the fact that water demand is increasingly higher than the supply. This also calls for paradigm shift from maximizing yield per unit 
land area to maximizing yield per water consumed. Both in irrigated and rainfed cropping systems, crop water productivity can be enhanced by choosing well-adapted crop types, reducing unproductive water losses and sustaining healthy, vigorously growing crops through optimized water, nutrient and agronomic management (Descheemaeker et al. 2013) [53]. Wallace (2000) [5] mentioned that strategies that will contribute to an increase in transpiration are likely to increase irrigation efficiency and CWP. Storage and conveyance losses reduce irrigation WUE of conventional irrigation methods hence reduce transpiration because less water reaches the root zone (Wallace, 2000) [5]. This will ultimately reduce CWP as well. Interventions that reduces evaporation losses, runoff losses and deep percolation losses ensure that a large portion of water is channeled into plant transpiration, a means by which plant consume water. Evans and Sadler (2008) [54] provide a very comprehensive and informative review of the methods and techniques for increasing WUE and CWP under rainfed and irrigated systems. The proposed techniques include replacing non-water saving crops with water saving ones, replacing shallow-rooted crops with deep-rooted crops, growing high value crops with high economic productivity per unit water consumed and adoption of alternate drought resistant crops. They further suggest the implementation of a carefully managed deficit irrigation systems that are supported by advanced irrigation system and flexible, state-of-the-art water delivery systems. Agroforestry has been reported to increase CWP by integrating trees in the cropping system (Descheemaeker et al. 2013) [53]. Trees have high rooting depth, hence can access water beyond the root zone of the crops. Thus crops can be able to access water from deep aquifers through association with trees. However, a challenge is the selection of the appropriate tree species. The trees to be integrated with crops must be water-saving and should not compete with crops. The current low CWP values for many crops grown worldwide provide opportunities for implementing some interventions that will increase the productivity (Wallace, 2000) [5]. A study on the effect of management interventions on CWP by Brauman et al. (2013) [11] in rainfall-limited regions globally suggest that increasing CWP to the $20^{\text {th }}$ percentile of productivity would increase annual production on rainfed cropland by enough to provide food for an estimated 110 million people, and water use on irrigated cropland would be reduced enough to meet the annual domestic water demands of nearly 1.4 billion people.

\section{Constrains for Achieving Optimal CWP and Sustainable Water Resources Management}

Climate variability is one of the constrains for achieving optimal CWP level especially in water limited areas where rainfall is very erratic. The semi-arid and arid areas of Sub-Saharan Africa and South Mediterranean region are typical areas where achieving optimal CWP is highly constrained by climate variability (Wallace, $2000[5]$ ). Generally in these areas poor agricultural water manage- 
ment systems account for low CWP values. As mentioned in section 4, developing countries still lack technology and skills to implement sound agronomic and agricultural water management practices that will ensure high CWP and sustainable water resources management.

\section{Conclusion and Recommendations}

This paper has reviewed WUE and CWP indices as applied in agroecosystems at various temporal and spatial scales. The paper has clearly demonstrated the difference between the two terms and provided an account for the existing confusion of usage of the terms. A number of factors affecting CWP have been assessed together with measures for improvement. It was clear that WUE and CWP seem to be very critical water saving metrics in water-limited areas. The paper further documents that achieving optimal CWP and sustainable water resource management in developing countries is still challenges due to the fact that agriculture in those areas depends on smallholder farmers who are generally poor. It is therefore recommended that some technical and financial support should be given to developing countries to enable them achieve optimal CWP levels and sustainable water resources management. Globally it can be recommended that in order to ensure water saving, water-limited areas should invest in high value crops and use the proceeds to import food from other countries with enough water supply under virtual water trade agreements.

\section{Conflicts of Interest}

The author declares no conflicts of interest.

\section{References}

[1] UNEP (United Nations Environment Programme) (2002) Vital Water Graphics: An Overview of the State of the World's Fresh the Marine Waters. United Nations Environment Programme, Nairobi.

https://www.unep.org/resources/report/vital-water-graphics-overview-state-worldsfresh-and-marine-waters

[2] UNESCO (United Nations Educational, Scientific and Cultural Organization) (2003) Water for People, Water for Life. The United Nations World Water Development Report. Part II: A Look at World's Freshwater Resources. United Nations Educational, Scientific and Cultural Organization, Paris.

[3] Alcamo, J., Florke, M. and Marker, M. (2007) Future Long-Term Changes in Global Water Resources Driven by Socio-Economic the Climatic Changes. Hydrological Sciences Journal, 52, 247-275. https://doi.org/10.1623/hysj.52.2.247

[4] Zwart, S.J. and Bastiaanssen, W.G.M. (2004) Review of Measured Crop Water Productivity Values for Irrigated Wheat, Rice, Cotton the Maize. Agricultural Water Management, 69, 115-133. https://doi.org/10.1016/j.agwat.2004.04.007

[5] Wallace, J.S. (2000) Increasing Agricultural Water Use Efficiency to Meet Future Food Production. Agriculture Ecosystem \& Environment, 82, 105-119. https://doi.org/10.1016/S0167-8809(00)00220-6

[6] UNCTAD (United Nations Conference on Trade and Development) (2011) Water 
for Food: Innovative Water Management Technologies for Food Security the Poverty Alleviation. United Nations Conference on Trade and Development, Geneva.

[7] Rockstrom, J. and Falkenmark, M. (2000) Semi-Arid Crop Production from A Hydrological Perspective: Gap between Potential the Actual Yields. Critical Review in Plant Sciences, 19, 319-346. https://doi.org/10.1080/07352680091139259

[8] IWMI (International Water Management Institute) (2009) Rainfed Agriculture: Unlocking the Potential. International Water Management Institute, Oxfordshire.

[9] Lacirignola, C., Capone, R., Debs, P., El Bilali, H. and Bottalico, F (2014) Natural Resources-Food Nexus: Food-Related Environmental Footprints in the Mediterranean Countries. Frontiers in Nutrition, 1, Article No. 23.

https://doi.org/10.3389/fnut.2014.00023

[10] Rockström, J. and Karlberg, L (2010) The Quadruple Squeeze: Defining the Safe Operating Space for Freshwater Use to Achieve A Triply Green Revolution in the Anthropocene. AMBIO, 39, 257-265. https://doi.org/10.1007/s13280-010-0033-4

[11] Brauman, K., Siebert, S. and Jonathan, A. (2013) Improvements in Crop Water Productivity Increase Water Sustainability the Food Security-A Global Analysis. Environmental Research Letters, 8, Article ID: 024030. https://doi.org/10.1088/1748-9326/8/2/024030

[12] IWMI (International Water Management Institute) (2007) Pathways for Increasing Agricultural Water Productivity.

http://www.iwmi.cgiar.org/assessment/Water\%20for\%20Food\%20Water\%20for\%20 Life/Chapters/Chapter\%207\%20Water\%20Productivity.pdf

[13] Sadras, V.O., Grassin, I.P. and Steduto, P. (2011) Status of Water Use Efficiency of Main Crops. SOLAW Background Thematic Report-TR07. Food and Agriculture Organization of the United Nations, Rome, $41 \mathrm{p}$.

[14] Ragab, R. (2016) A Note on Water Use Efficiency the Water Productivity. http://www.water4crops.org/wp-content/uploads/2014/08/RR Water-use-efficiency -and-water-productivity.pdf

[15] United Nations World Commission on Environment the Development (UN WCED) (1987) Our Common Future: Report of the World Commission on Environment the Development. Document A/42/427, United Nations, New York.

[16] Mays, L. (2006) Water Resources Sustainability. McGraw-Hill Professional, New York.

[17] Russo, T., Alfredo, K. and Fisher, J. (2014) Sustainable Water Management in Urban, Agricultural, the Natural Systems. Water, 6, 3934-3956. https://doi.org/10.3390/w6123934

[18] Duran, D.C., Gogan, L.M., Artene, A. and Duran, V. (2015) The Components of Sustainable Development-A Possible Approach. Procedia Economics the Finance, 26, 806-811. https://doi.org/10.1016/S2212-5671(15)00849-7

[19] Molden, D., Oweis, T., Steduto, P., Bindraban, P., Hanjra, M.A. and Kijne, J. (2010) Improving Agricultural Water Productivity: Between Optimism the Caution. Agricultural Water Management, 97, 528-535.

https://doi.org/10.1016/j.agwat.2009.03.023

[20] Passioura, J. (2005) Increasing Crop Productivity When Water Is Scarce-from Breeding to Field Management. Agricultural Water Management, 80, 176-196. https://doi.org/10.1016/j.agwat.2005.07.012

[21] Viets, F.G. (1962) Fertilizers the Efficient Use of Water. Advances in Agronomy, 14, 223-264. https://doi.org/10.1016/S0065-2113(08)60439-3 
[22] Viets, F.G. (1966) Increasing Water Use Efficiency by Soil Management. In: Pierre, W.H., Kirkham, D., Pesek, J. and Shaw, R., Eds., Plant Environment the Efficient Water, American Society of Agronomy, The Soil Science Society of America, Madison.

[23] Condon, A.G., Richards, R.A., Rebetzke, G.J the Farquhar, G.D. (2002) Improving Intrinsic Water-Use Efficiency the Crop Yield. Crop Science, 42, 122-131. https://doi.org/10.2135/cropsci2002.1220

[24] Medrano, H., Flexas, J., Ribas-Carbo, M. and Gulias, J. (2010) Measuring Water Use Efficiency in Grapevines. In: Delrot, S., Medrano, H., Or, E., Bavaresco, L. and Grando, S., Eds., Methodologies the Results in Grapevine Research, Springer, Dordrecht, 123-134. https://doi.org/10.1007/978-90-481-9283-0 9

[25] Seckler, D., Molden, D. and Sakthivadivel, R. (2003) The Concept of Efficiency in Water Resources Management the Policy. In: Kijne, J.W., Barker, R. and Molden, D., Eds., Water Productivity in Agriculture: Limits the Opportunities for Improvement, CABI Publishing the International Water Management Institute, Wallingford, Colombo, 37-52. https://doi.org/10.1079/9780851996691.0037

[26] Cai, X., Sharma, B.R., Matin, M.A., Sharma, D. and Gunasinghe, S. (2010) An Assessment of Crop Water Productivity in the Indus the Ganges River Basins: Current Status the Scope for Improvement. International Water Management Institute, Colombo, Sri Lanka, 30 p. https://doi.org/10.5337/2010.232

[27] Perry, C. (2011) Accounting for Water Use: Terminology the Implications for Saving Water the Increasing Production. Agricultural Water Management, 98, 1840-1846. https://doi.org/10.1016/j.agwat.2010.10.002

[28] Jensen, M.E. (1967) Evaluating Irrigation Efficiency. Journal of the Irrigation and Drainage Division, 93, 83-98. https://doi.org/10.1061/JRCEA4.0000485

[29] Jensen, M. (2007) Beyond Irrigation Efficiency. Irrigation Science, 25, 233-245. https://doi.org/10.1007/s00271-007-0060-5

[30] Heydari, N. (2014) Water Productivity in Agriculture: Challenges in Concepts, Terms the Values. Irrigation and Drainage, 63, 22-28. https://doi.org/10.1002/ird.1816

[31] Israelsen, O.W. (1950) Irrigation Principles the Practices. Wiley, New York, 471.

[32] Molden, D. (1997) Accounting for Water Use the Productivity. System Wide Initiave for Water Management (SWIM) Institute, Colombo.

[33] Sharma, B.R., Molden, D. and Cook, S. (2015) Water Use Efficiency in Agriculture: Measurement, Current Situation the Trends. In: Drechsel, P., Heffer, P., Magan, H., Mikkelsen, R. and Wichlens, D., Eds., Managing Water the Fertiliser for Sustainable Intensification, International Fertiliser Association, Paris; International Water Management Institute, Colombo; International Plant Nutrition Institute, Georgia; International Potash Institute, Horgen, 39-64.

[34] Medrano, H., Magdalena, T., Martorell, S., Flexas, J., Hernández, E., Rosselló, J., Pou, A., Escalona, J.-M. and Bota, J. (2015) From Leaf to Whole-Plant Water Use Efficiency (WUE) in Complex Canopies: Limitations of Leaf WUE As A Selection Target. The Crop Journal, 3, 220-228. https://doi.org/10.1016/j.cj.2015.04.002

[35] Cirelli, D., Lieffers, V.J. and Tyree, M.T. (2012) Measuring Whole-Plant Transpiration Gravimetrically: A Scalable Automated System Built from Components. Trees, 26, 1669-1676. https://doi.org/10.1007/s00468-012-0731-6

[36] Spano, D., Duce, P. and Snyder, R.L. (2004) Estimate of Mass the Energy Fluxes Over Grapevine Using Eddy Covariance Technique. Acta Horticulturae, 664, 
631-638. https://doi.org/10.17660/ActaHortic.2004.664.79

[37] Tang, X., Li, H., Desai, A.R., Nagy, Z., Luo, J., Kolb, T.E., et al. (2014) How Is Water-Use Efficiency of Terrestrial Ecosystems Distributed the Changing on Earth? Scientific Reports, 4, Article No. 7483. https://doi.org/10.1038/srep07483

[38] Vanloocke, A., Twine, T.E., Zeri, M. and Bernacchi, C.J. (2012) A Regional Comparison of Water Use Efficiency for Miscanthus, Switchgrass the Maize. Agricultural the Forest Meteorology, 164, 82-95. https://doi.org/10.1016/j.agrformet.2012.05.016

[39] Cook, B.D., Holladay, S., Santhana-Vannan, S.K., Pan, J.Y., Jackson, B. and Wilson, B. (2007) FLUXNET: Data from a Global Network of Eddy-Covariance Flux Towers. Eos, Transactions, American Geophysical Union, 88, Abstract B33E-1656.

[40] Connor, D.J., Loomis, R.S. and Cassman, K.G. (2011) Crop Ecology: Productivity the Management in Agricultural Systems. 2nd Edition, Cambridge University Press, Cambridge.

[41] Silva, L.L., Duarte, I., Lourenco, E., Simões, N the Chaves, M.M. (2014) Yield the Water Productivity of Five Chickenpea Varieties under Supplemental Irrigation in Contrasting Years. Irrigation Science, 32, 393-403.

https://doi.org/10.1007/s00271-014-0437-1

[42] Sadras, O.V. and McDonald, G. (2012) Water Use Efficiency of Grain Crops in Australia: Principles, Benchmarks the Management. Grains Research the Development Corporation, South Australian Research the Development Institute, the University of Adelaide, Adelaide.

[43] Will, R.E., Wilson, S.M., Zou, C.B. and Hennessey, T.C. (2013) Increased Vapor Pressure Deficit Due to Higher Temperature Leads to Greater Transpiration the Faster Mortality during Drought for Tree Seedlings Common to the Forest grassland Ecotone. New Phytologist, 200, 366-374. https://doi.org/10.1111/nph.12321

[44] McDowell, N., Pockman, W.T., Allen, C.D., Breshears, D.D., Cobb, N., Kolb, T., Plaut, J., Sperry, J., West, A. and Williams, D.G. (2008) Mechanisms of Plant Survival the Mortality During Drought: Why Do Some Plants Survive While Others Succumb to Drought? New Phytologist, 178, 719-739.

https://doi.org/10.1111/j.1469-8137.2008.02436.x

[45] Sinclair, T.R., Zwieniecki, M.A. and Holbrook, N.M. (2008) Low Leaf Hydraulic Conductance Associated With Drought Tolerance in Soybean. Physiologia Plantarum, 132, 446-451. https://doi.org/10.1111/j.1399-3054.2007.01028.x

[46] Grimmer, M.K., Foulkes, M.J. and Paveley, N.D. (2012) Foliar Pathogenesis the Plant Water Relations: A Review. Journal of Experimental Botany, 63, 4321-4331. https://doi.org/10.1093/jxb/ers143

[47] Jha, A.K., Malla, R., Sharma, M., Panthi, J., Lakhankar, T., Krakauer. N.Y., Pradhanag, S.M., Dahal, P. and Shrestha, M.L. (2016) Impact of Irrigation Method on Water Use Efficiency the Productivity of Fodder Crops in Nepal. Climate, 4, Article No. 4. https://doi.org/10.3390/cli4010004

[48] Igbadun, H.E., Salim, B.A., Tarimo, A.K.P.R. and Mahoo, H.F. (2008) Effects of Deficit Irrigation Scheduling on Yields the Soil Water Balance of Irrigated Maize. Irrigation Science, 27, 11-23. https://doi.org/10.1007/s00271-008-0117-0

[49] Li, F.-M., Song, Q.-H., Liu, H.-S., Li, F.-R. and Liu, X.-L. (2001) Effects of Pre-Sowing Irrigation the Phosphorus Application on Water Use the Yield of Spring Wheat Under Semi-Arid Conditions. Agricultural Water Management, 49, 173-183. https://doi.org/10.1016/S0378-3774(01)00087-7

[50] Kröbel, R., Campbell, C.A., Zentner, R.P., Lemke, R., Steppuhn, H., Desjardins, R. 
L. and De Jong, R. (2012) Nitrogen the Phosphorus Effects on Water Use Efficiency of Spring Wheat Grown in A Semi-Arid Region of the Canadian Prairies. Canadian Journal of Soil Science, 92, 573-587. https://doi.org/10.4141/cjss2011-055

[51] Rudnick, D.R. and Irmak, S. (2013) Impact of Water the Nitrogen Management Strategies on Maize Yield the Water Productivity Indices under Linear-Move Sprinkler Irrigation. Transactions of the American Society of Agricultural the Biological Engineers, 56, 1769-1783. https://doi.org/10.13031/trans.56.10215

[52] Hatfield, J.L., Sauer, T.J. and Prueger, J.H. (2001) Managing Soils to Achieve Greater Water Use Efficiency: A Review. Agronomy Journal, 93, 271-280. https://doi.org/10.2134/agronj2001.932271x

[53] Descheemaeker, K., Bunting, S.W., Bindraban, P., Muthuri, C., Molden, D., Beveridge, M., Van Brakel, M., Herrero, M., Clement, F., Boelee, E. and Jarvis, D.I. (2013) Increasing Water Productivity in Agriculture. In: Boelee, E., Ed., Managing Water the Agroecosystems for Food Security, CAB International, Wallingford, 104-123. https://doi.org/10.1079/9781780640884.0104

[54] Evans, R.G. and Sadler, E.J. (2008) Methods the Technologies to Improve Efficiency of Water Use. Water Resources Research, 44, Article No. W00E04.

https://doi.org/10.1029/2007WR006200 